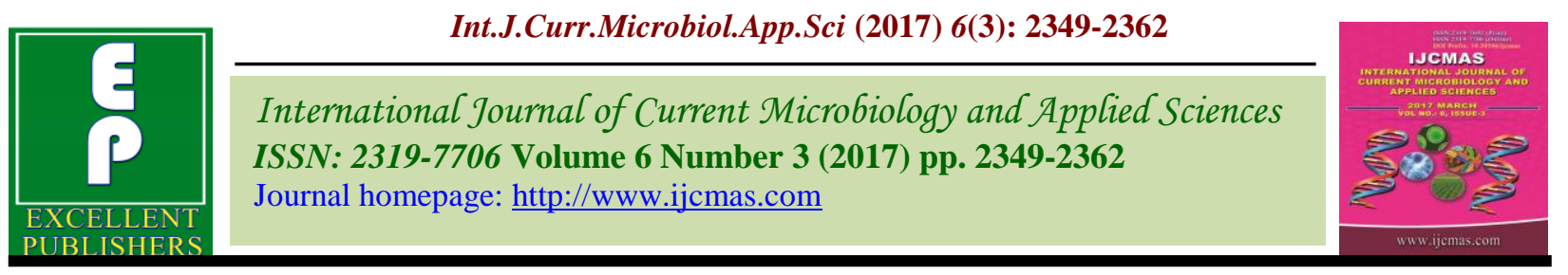

Original Research Article

http://doi.org/10.20546/ijcmas.2017.603.269

\title{
A Novel Alkaline, Highly Thermostable and Oxidant Resistant Carboxymethyl Cellulase (Cmcase) Produced by Thermophilic Bacillus sonorensis CY-3
}

\author{
Yasemin Caf $^{1,2 *}$ and Burhan Arikan ${ }^{1}$ \\ ${ }^{1}$ Biotechnology Department, Institute of Basic and Applied Sciences, \\ Cukurova University, Turkey \\ ${ }^{2}$ Molecular Biology and Genetics Department, Institute of Basic and Applied Sciences, \\ Avrasya University, Turkey \\ *Corresponding author
}

\begin{tabular}{|c|c|}
\hline & A B S T R A C T \\
\hline Keywords & \multirow{4}{*}{$\begin{array}{l}\text { The bacterial strain a thermophilic carboxymethyl cellulase-producing was } \\
\text { screened from biocompost. The strain was identified as Bacillus sonorensis CY-3 } \\
\text { according to morphological, biochemical and molecular analysis, then it was } \\
\text { optimized for the production of carboxymethyl cellulase (CMCase). Enzyme was } \\
\text { optimally produced in a Luria Broth (LB) medium containing carboxymethyl } \\
\text { cellulose (CMC) at pH } 9.0 \text { and } 55^{\circ} \mathrm{C} \text {. Two bands were found with molecular mass } \\
80 \mathrm{kDa} \text { and } 72 \mathrm{kDa} \text { by use SDS-PAGE and the Vmax and Km were measured } \\
380.19 \mathrm{U} / \mathrm{ml} \text { and } 5.82 \mathrm{mg} / \mathrm{ml} \text {, respectively. The partially purified enzyme has } \\
\text { showed optimal activity at pH } 9.0 \text { and } 100^{\circ} \mathrm{C} \text { while it was stabled from pH } 6.0 \text { to } \\
13.0 \text { with more than } 65 \% \text { activity. It was found to have the properties of enzyme } \\
\text { highly thermostability, pH stability, and stability in the presence of some additives } \\
\text { that made potentially useful in textile, laundry, and other industrial applications. }\end{array}$} \\
\hline $\begin{array}{l}\text { Bacillus sonorensis, } \\
\text { Thermostable } \\
\text { enzyme, Cellulase } \\
\text { activity, Oxidant } \\
\text { residance, } \\
\text { Carboxymethylcellu } \\
\text { lose. }\end{array}$ & \\
\hline Article Info & \\
\hline $\begin{array}{l}\text { Accepted: } \\
\text { 24 February } 2017 \\
\text { Available Online: } \\
\text { 10 March } 2017\end{array}$ & \\
\hline
\end{tabular}

\section{Introduction}

Cellulosic materials, which is the product of plant biomass that compose the cell of all higher plants, is the most renewable and abundant source of fermentable carbohydrates in the world (Christakopoulos et al., 1999). They hydrolyzed into soluble sugars by cellulases. Cellulases are hydrolysing the $\beta$ 1,4 linkages in cellulose. This cellulolytic activity occurs by the synergistic effect of three major components; endo- $\beta$-glucanase (EC 3.2.1.4), exo- $\beta$-glucanase (EC 3.2.1.91) and $\beta$-glucosidase (EC 3.2.1.21) and they are classified into two groups: endoglucanases (EC 3.2.1.4) and cellobiohydrolases (EC 3.2.1.91) (Cavaco-Paulo, 1998; Christakopoulos et al., 1999; Xu et al., 2007; Liu et al., 2008; Das et al., 2010). Alkaliphilic Bacillus sp. produce a massive amount of extracellular alkaline adapted enzymes such as amylases, cellulases, pectinases and proteases, that they are good and advantageous in industry (Singh et al., 2004; Fujinama and Fujisawa, 2010). The potential of cellulases has been revealed in a broad 
range of processes in the textile such as biopolishing, biostoning and stonewashing; furthermore they are used for the production of food, energy, laundry detergent additives and with xylanases for deinking of waste paper (Nielsen et al., 2007; Fujinama and Fujisawa, 2010).

In this study we have purified and characterised an alkaline, thermophilic, oxidant residance CMCase from thermophilic Bacillus sp. CY-3.

\section{Materials and Methods}

\section{Bacterial strain and culture conditions}

Alkaline CMCase-producing Bacillus sp. CY3 were screened from alkaline soil samples near agricultural waste in Adana, Turkey. For selection of gram-positive spore forming bacteria the samples were incubated at $80^{\circ} \mathrm{C}$ for $10 \mathrm{~min}$ (Chang et al., 2012). Cultures were subjected to single-colony isolation on the solid medium at $55^{\circ} \mathrm{C}$ for $26 \mathrm{~h}$. Following, the single-colonies were grown on CMC containing solid medium containing: $\left(\mathrm{g} / \mathrm{l}^{-1}\right)$ : Pepton 10, Yeast extract 5, $\mathrm{NaCl} 5, \mathrm{CMC} \mathrm{6}$, Agar agar 15; the $\mathrm{pH}$ was adjusted to 9.0 with $\mathrm{NaOH}$ (set prior to sterilization) at $55^{\circ} \mathrm{C}$ for 26h. Afterward, CMCase positive isolates were determined staining with Congo Red solution (1\%) (Chang et al., 2012, Wang et al., 2010).

The strain was identified by studying its morphological and biochemical characteristics (Xu et al., 2007; Vos et al., 2009; Caf et al., 2012) Molecular identification of the strain was carried out by analyzing of its $16 \mathrm{~S}$ rDNA gene sequences. The extraction of genomic DNA and $16 \mathrm{~S}$ rDNA amplification was realized by the polymerase chain reaction (PCR) with two universal primers. Subsequently, the PCR pruduct was purified by Wizard ${ }^{\circledR} \mathrm{SV}$ Gel and PCR Clean-Up System-Promega.
The sequence of the isolate was aligned with those in the NCBI GenBank database for similarity search and were performed by using ClustalW software and MEGA6.06 program. The philogenetic trees were created using the neighbour-joining method (Balasubramanian and Simoes, 2014; Caf et al., 2014).

\section{Optimization of medium composition}

Culture conditions such as different temperatures, pHs, carbon and nitrogen sources, salt concentrations, and substrate (CMC) concentrations were optimized for enzyme production.

For this purpose production medium containing different carbon sources (fructose, glucose, maltose and sucrose) and different nitrogen sources (beef extract, yeast extract, tryptone, casein and peptone), different $\mathrm{NaCl}$ concentrations $(0.1-1 \%$, with increments of $0.1 \%)$, different CMC concentration $(0.1-1 \%$, with increments of $0.1 \%$ ) and incubated under different temperature $\left(0-50^{\circ} \mathrm{C}\right.$, with increments of $5^{\circ} \mathrm{C}$ ) and $\mathrm{pH}(3.0-9.0$ with increments of one unit) were analyzed for enzyme production by the selected Bacillus strain (Shanmughapriya et al., 2010; Caf et al., 2012; Caf et al., 2014).

\section{Enzyme production}

Strain Bacillus CY-3 was grown under optimized culture condition in the $0.6 \% \mathrm{CMC}$ medium at $55^{\circ} \mathrm{C}$ for $26 \mathrm{~h}$ at $190 \mathrm{rev} / \mathrm{min}$. The culture was centrifuged at $8000 \mathrm{x} \mathrm{g}$ at $4^{\circ} \mathrm{C}$ for $15 \mathrm{~min}$ and the supernatant was used for partial purification and biochemical characterization (Caf et al., 2012; Caf et al., 2014).

\section{Partial purification of crude enzyme}

The supernatant of culture was precipitated with chilled acetone and was left at $-30^{\circ} \mathrm{C}$ for 
4 h. The precipitate was recovered by centrifugation at $12000 \mathrm{x}$ g for $20 \mathrm{~min}$ at $4^{\circ} \mathrm{C}$. After centrifugation the sediment, dissolved in phosphate buffer $(1 \mathrm{mM})$ at $\mathrm{pH} 7.0$ (Chang et al., 2012).

\section{Estimation of protein content}

The protein content in the partial purified Enzyme solution was estimated by the method of Lowry (Hafiz, 2005; Lowry, 1951).

\section{Enzyme assay}

Diluted enzyme solution, $0.5 \mathrm{ml}$ was mixed with $0.5 \mathrm{ml} 1 \%$ (w/v) $\mathrm{CMC}$ in $0.1 \mathrm{M}$ glycine $/ \mathrm{NaOH}$ buffer, $\mathrm{pH} 9.0$, and incubated at optimum temperature for $60 \mathrm{~min}$. The reaction was stopped by the addition of 3.5dinitrosalicylic acid (DNS) solution, boiled for $5 \mathrm{~min}$, and then cooled in water. The absorbance was measured at $540 \mathrm{~nm}$ in a 5500 spectrophotometer (Christakopoulos et al., 1999; Arikan et al., 2003; Rastogi et al., 2010).

Influence of $\mathrm{pH}$, temperature on the enzyme activity and stability

The optimum $\mathrm{pH}$ activity of enzyme was determined using different $\mathrm{pH}$ buffers: $0.01 \mathrm{M}$ sodium phosphate buffer ( $\mathrm{pH} 6.0-8.0), 0.01 \mathrm{M}$ glycine buffer ( $\mathrm{pH}$ 8.0-10.0), 0.01M borax buffer ( $\mathrm{pH}$ 11.0-13.0). And the optimum temperature was tested at different temperatures $\left(20-110^{\circ} \mathrm{C}\right)$ for $1 \mathrm{~h}$. The $\mathrm{pH}$ stability study of the partial purified enzyme was measured after $1 \mathrm{~h}$ of preincubation in different $\mathrm{pH}$ buffers. Afterward residual activity was determined under optimized assay conditions considering control as $100 \%$. The temperature stability was measured by preincubating the enzyme at different temperatures for $1 \mathrm{~h}$. The residual activity was determined at optimum temperature for at optimum temperature for $60 \mathrm{~min}$ considering control as 100\% (Das et al., 2010; Chang et al., 2012).

Influence of different $\mathrm{NaCl}$ concentrations on enzyme stability

The stability of enzyme was measured under optimized assay conditions considering control as $100 \%$ at different $\mathrm{NaCl}$ concentrations $(0.5-5 \mathrm{M})$ after pre- incubation at $55^{\circ} \mathrm{C}$ for $60 \mathrm{~min}$ (Caf et al., 2012).

\section{Influence of effectors on enzyme activity}

For measurement the effect of various additives the enzyme was pre-incubated at $55^{\circ} \mathrm{C}$ for $60 \mathrm{~min}$ in different effectors. Afterward residual activity was determined under optimized assay conditions considering control as 100\% (Chang et al., 2012, Caf et al., 2014).

\section{Determination of Molecular Weight and Zymogram Analyses}

The molecular weight of the partially purified enzyme was determined using sodium dodecyl sulfate polyacrylamide gel electrophoresis (SDS-PAGE) with 5\% stacking gel and 10\% separating gel including CMC (0.1\%). Molecular weight was determined by comparing of Standard protein molecular weight markers (Sigma SDS6H2, 29.000, 45.000, 66.000, 97.000, 116.000, 200.000 Da). After electrophoresis the gel was cut into two pieces, markers was stained with Coomasie Brillant Blue R-260 and destained with methanol-acetic asid-water solution $(1: 1: 8)$, other piece was subjected to renaturation solutions containing (I,II and III) containing: Renaturation solution I: $50 \mathrm{mM}$ $\mathrm{Na}_{2} \mathrm{HPO}_{4}, \quad 50 \quad \mathrm{mM} \quad \mathrm{NaH}_{2} \mathrm{PO}_{4} \quad(\mathrm{pH} \quad 7.2)$, isopropanol $40 \%$ for $1 \mathrm{~h}$. Renaturation solution II: $50 \mathrm{mM} \quad \mathrm{Na}_{2} \mathrm{HPO}_{4}, \quad 50 \mathrm{mM}$ $\mathrm{Na}_{2} \mathrm{HPO}_{4}(\mathrm{pH}$ 7.2) for $1 \mathrm{~h}$ and at last in renaturation solution III: $50 \mathrm{mM} \mathrm{Na} \mathrm{HPO}_{4}, 50$ $\mathrm{mM} \quad \mathrm{Na}_{2} \mathrm{HPO}_{4} \quad(\mathrm{pH} \quad 7.2), \quad 5 \quad \mathrm{mM} \quad \beta-$ 
mercaptoethanol and $1 \mathrm{mM}$ EDTA at $4^{\circ} \mathrm{C}$ overnight, respectively. After that, the gel was incubated at $45^{\circ} \mathrm{C}$ for $5 \mathrm{~h}$ and stained with Congo red (Chang et al., 2012, Shanmughapriya et al., 2010).

\section{Chromatography of hydrolysed products}

Enzyme solution $2 \mathrm{ml}$ was incubated with 0.5 $\mathrm{ml} \mathrm{2 \%}$ (w/v) $\mathrm{CMC}$ in $0.1 \mathrm{M}$ glycine/ $\mathrm{NaOH}$ buffer, $\mathrm{pH}$ 9.0, and incubated at optimum temperature for $60 \mathrm{~min}$. And the hydrolysis products $(0.5 \mu \mathrm{l})$ were assayed on silica gel plates using a chloroform: acetic acid: water (6:7:1) solvent system. Afterward, the spots were visualized by spraying with aceton solution including: aniline $(1.0 \%, \mathrm{v} / \mathrm{v})$, diphenylamine $(1.0 \%, \mathrm{w} / \mathrm{v})$, orthophosphoric acid $(10 \%, v / \mathrm{v})$ and baking in oven at $120^{\circ} \mathrm{C}$ for 45 min (Singh et al., 2001; Voget et al., 2006).

\section{Kinetic determination}

Kinetic studies were performed with different CMC concentrations $(0.05-0.5 \%)$ and times (0-30 min) in $50 \mathrm{mM}$ glycine- $\mathrm{NaOH}$ buffer $(\mathrm{pH} 9.0)$ at $80^{\circ} \mathrm{C}$. The kinetic constant $\mathrm{Km}$ and Vmax were determined according to Lineweaver-Burk double reciprocal plot (Trivedi et al., 2011; Caf et al., 2012).

\section{Results and Discussion}

\section{Isolation of alkaline thermophilic Bacillus} sp.

A total of 8 Bacillus sp. isolates secreting protease negative alkaline cellulase were screened from biocompost-waste, were selected from 84 colonies secreting alkaline cellulase. Of these, isolate CY-3 showed a large zone of hydrolysis and exhibit significant enzyme activity on was selected for cellulase production. The isolate was Gram positive, rod shaped, spore forming bacterium and aerobic. With the respect to this results of various morphological and biochemical characteristic, it was identified as belonging to the genus Bacillus. The strain grew well between $30-60^{\circ} \mathrm{C}$ and at a wide $\mathrm{pH}$ range of 8.0 to 11.0 and the optimum enzyme synthesis occurred at $55^{\circ} \mathrm{C}$ and $\mathrm{pH} 9.0$ on CMC plate.

\section{Determination of molecular mass}

Partial purified cellulase appeared as two different polypeptide band on SDS-PAGE and had the molecular masses of $80 \mathrm{kDa}$ and 72 $\mathrm{kDa}$, respectively (As shown in Fig.1.). Both protein also showed clear bands on the zymogram gel. Although, the cellulase activity band for $72 \mathrm{kDa}$ protein was faintly.

\section{pH and temperature optima and stability} of carboxymethylcellulase (CMCase)

A $\mathrm{pH}$ range from 6.0 to 12.0 was used to study the effect of $\mathrm{pH}$ on enzyme activity. The optimum activity was observed at $\mathrm{pH} 9.0$ and there was another peak at $\mathrm{pH} 11.0$ (about 83\%) (As shown in Fig.2.). And it was almost completely stable from $\mathrm{pH} 6.0$ to 12.0 with about $70 \%$ residual activity (As shown in Fig.3.). The optimum temperature of endoglucanase was $100^{\circ} \mathrm{C}$ (As shown in Fig.4.) and the enzyme was stable with more than $85 \%$ residual activity in different temperature $\left(20-110^{\circ} \mathrm{C}\right)$ (Fig. 5).

\section{Effect of various effectors}

The residual enzyme activity result have given in Table I. The Enzyme was slightly inhibited in the presence of $5 \mathrm{mM}$ EDTA, $\mathrm{MnCl}_{2}, \mathrm{ZnCl}_{2}, \mathrm{MgCl}_{2}, 1 \%$ SDS, Triton-X100, $0.1 \%$ Tween 20, Tween 80, mercaptoethanol, $5 \mathrm{mM}$ phenontroline, $3 \mathrm{mM}$ PMSF, iadoasetamide and $8 \mathrm{mM}$ urea up to $34,53,29,36,17,32,31,29,26,33,13,34$, and 30 respectively. On the other hand, it was 
increased in the presence of $\mathrm{CaCl}_{2}, \mathrm{CoCl}_{2}$ and $\mathrm{H}_{2} \mathrm{O}_{2}$ (31, 21 and $16 \%$, respectively).

Effect of different $\mathrm{NaCl}$ concentration on carboxymethylcellulase (CMCase) activity and stability

The activity was stable in different $\mathrm{NaCl}$ concentration from 3 to $30 \%$ with more than $66^{\circ} \mathrm{C}$ activity (As shown in Fig.6.).

\section{Chromatography of hydrolysed products}

After $2 \mathrm{~h}$ incubation of enzyme-substrate mixture, the thin layer chromatography of the CMC hydrolysate revealed the presence of maltoz, maltotrioz, etc. This result suggested that the CMCase called CY-3 is a very good producer of maltose (Fig. 7).

Table.1 Effect of different effectors with various concentration on the activity of carboxymethyl cellulase (CMCase) from Bacillus sp. CY-3

\begin{tabular}{|c|c|c|}
\hline Effectors & Concentration & Relative enzyme activity (\%) \\
\hline Control & None & 100 \\
\hline EDTA & $5 \mathrm{mM}$ & 65 \\
\hline $\mathrm{CaCl}_{2}$ & $5 \mathrm{mM}$ & 131 \\
\hline $\mathrm{CoCl}_{2}$ & $5 \mathrm{mM}$ & 121 \\
\hline $\mathrm{MnCl}_{2}$ & $5 \mathrm{mM}$ & 47 \\
\hline $\mathrm{ZnCl}_{2}$ & $5 \mathrm{mM}$ & 71 \\
\hline $\mathrm{MgCl}_{2}$ & $5 \mathrm{mM}$ & 64 \\
\hline SDS & $1 \%$ & 83 \\
\hline Triton X-100 & $1 \%$ & 68 \\
\hline Tween 20 & $0,1 \%$ & 69 \\
\hline Tween 80 & $0,1 \%$ & 71 \\
\hline$\beta$-mercaptoethanol & $1 \%$ & 75 \\
\hline 1,10-phenantroline & $5 \mathrm{mM}$ & 67 \\
\hline Idoasetamide & $3 \mathrm{mM}$ & 66 \\
\hline PMSF & $3 \mathrm{mM}$ & 87 \\
\hline Urea & $8 \mathrm{M}$ & 69 \\
\hline $\mathrm{H}_{2} \mathrm{O}$ & $0,1 \%$ & 11 \\
\hline
\end{tabular}


Fig.1 SDS-PAGE zymogram analyse of CY-3 carboxymethyl cellulase (CMCase).

Sodium dodecyl sulfate polyacrylamide gel electrophoresis (SDS-PAGE) with 5\% stacking gel and 10\% separating gel including 0.1\% CMC. Lane 1 and 2) Fragments resulting by CY-3 carboxymethyl cellulase activity produced by $B$. sonorensis CY-3 stained with \%0.1 Congo red; Lane 3) Molecular weight marker (29-200 kDa) stained with Coomasie Brillant Blue R-260

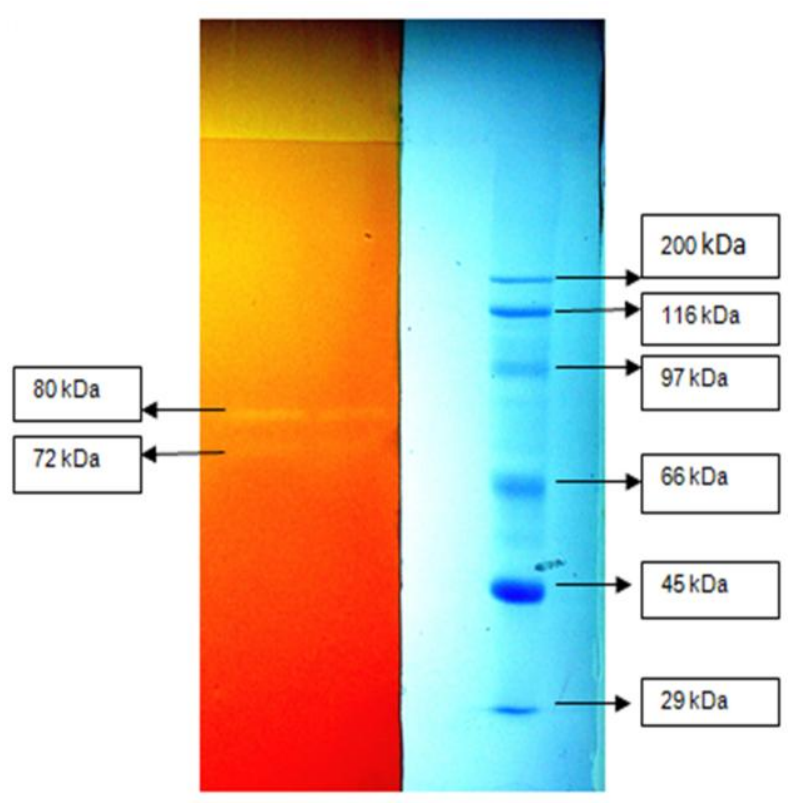

Fig.2 Effect of $\mathrm{pH}$ on the activity of $\mathrm{CY}-3$ carboxymethyl cellulase (CMCase)

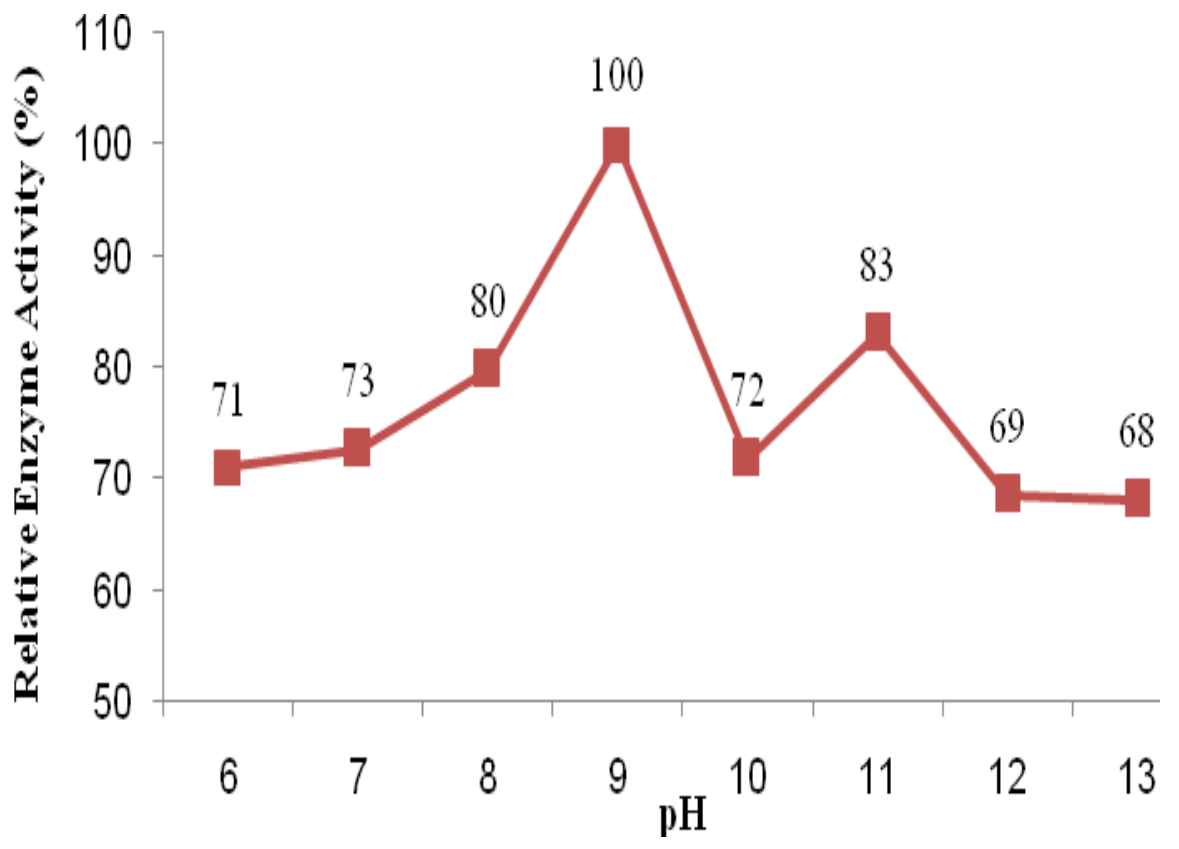


Fig.3 Effect of $\mathrm{pH}$ on the stability of $\mathrm{CY}-3$ carboxymethyl cellulase (CMCase)

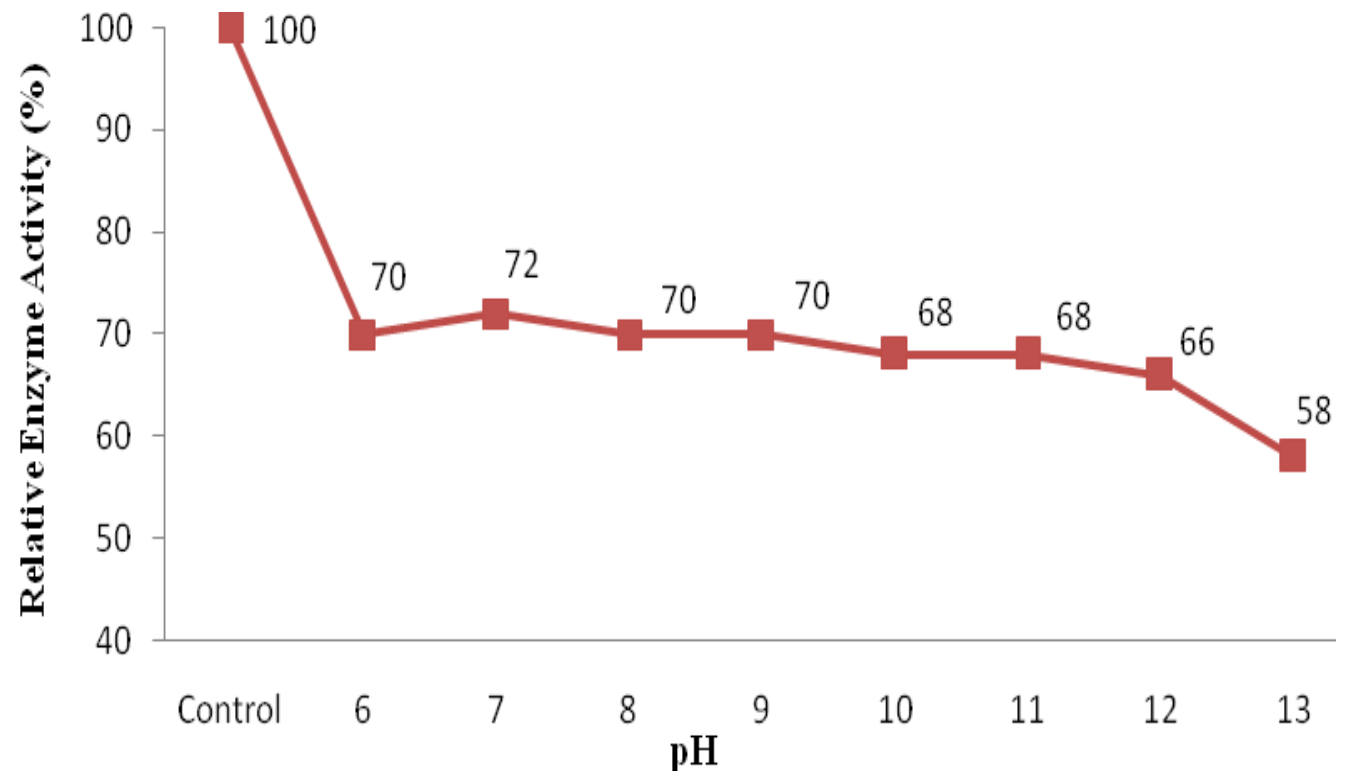

Fig.4 Effect of temperature on the activity of CY-3 carboxymethyl cellulase

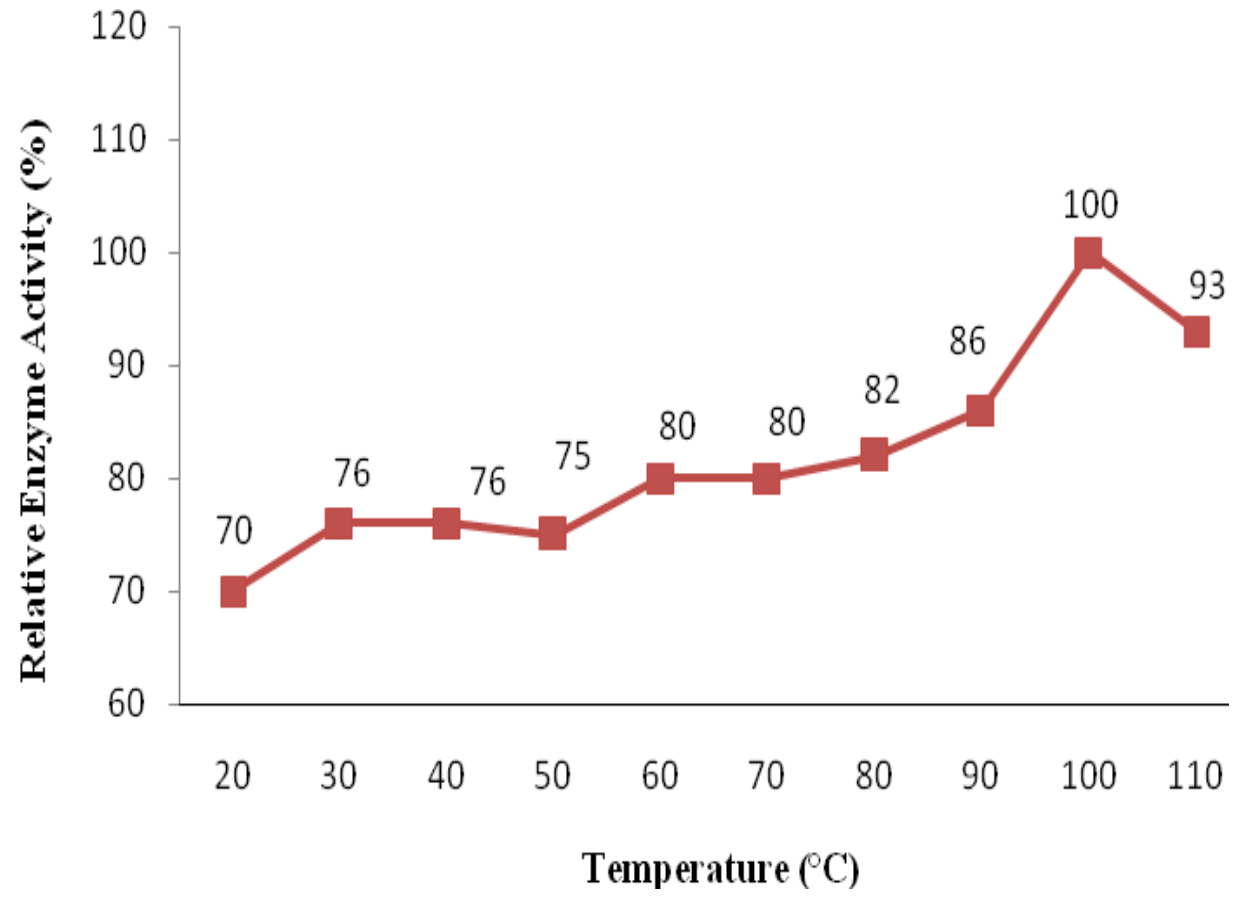


Fig. 5. Effect of thermal stability of CY-3 carboxymethyl cellulase (CMCase)

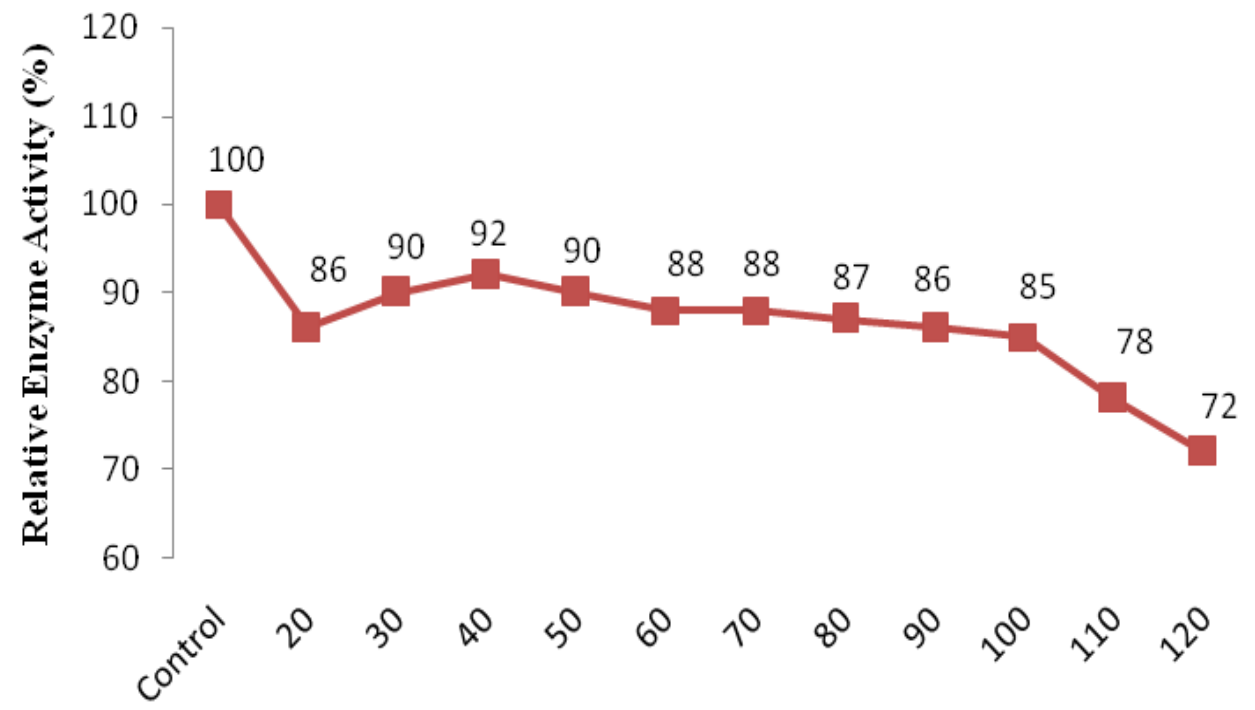

Temperature $\left({ }^{\circ} \mathrm{C}\right)$

Fig.6 Effect of different $\mathrm{NaCl}$ concentration on $\mathrm{CY}-3$ carboxymethyl cellulase (CMCase) activity

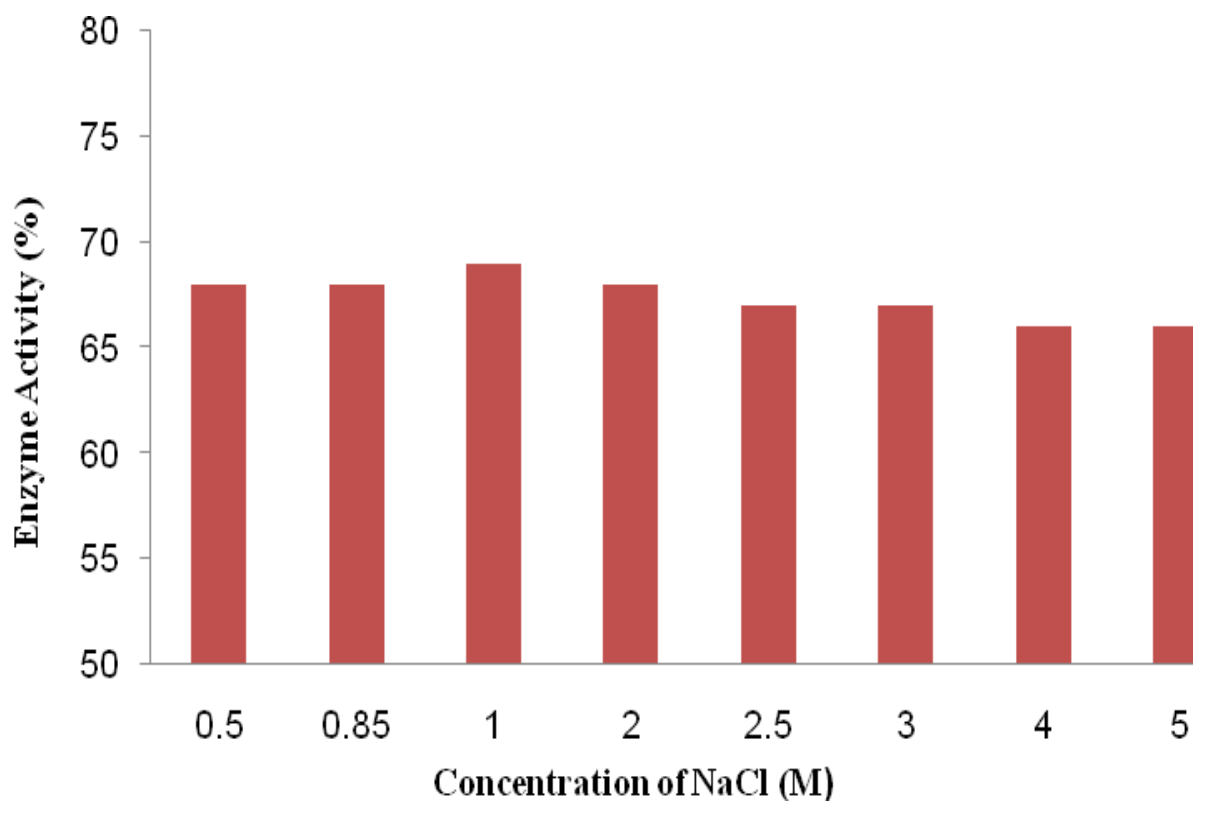


Fig.7 Thin layer chromatography showing the hydrolysed end products of carboxymethyl cellulase (CMCase) from Bacillus sonorensis CY-3

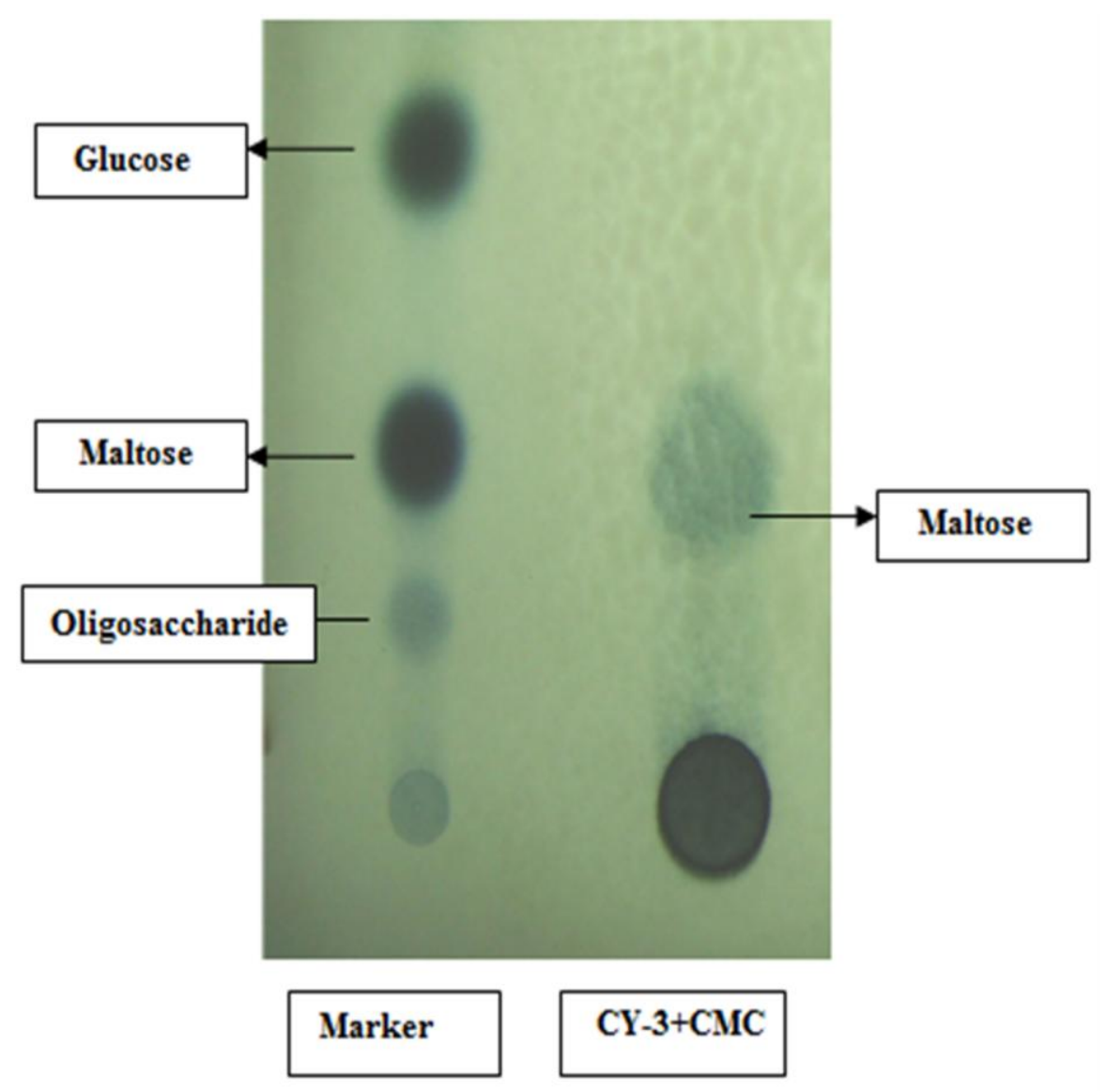

Fig.8 Phylogenetic tree of isolate Bacillus sp. CY-3 showing the relationship with other members of the genus Bacillus sp. using 16S rDNA sequence

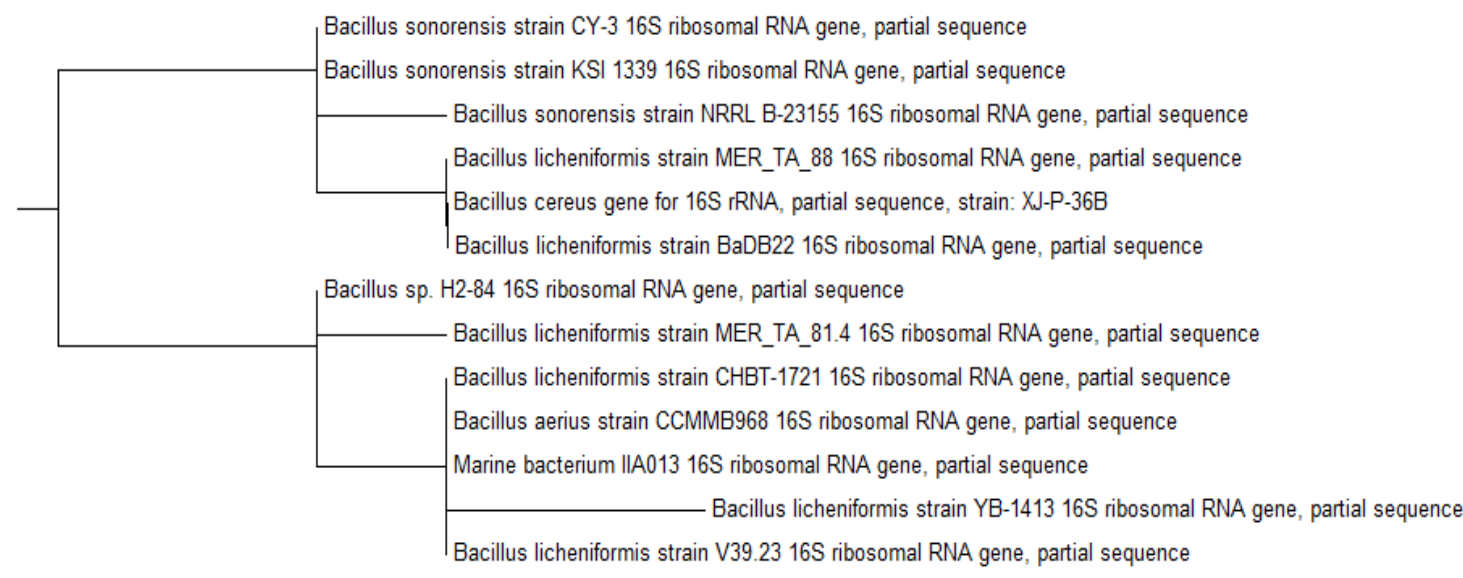

$\longmapsto .0005$ 
Isolate CY-3 was showed the largest zone of hydrolysis and was selected for cellulase production. The diameter of halo directly reflected the ability to produce cellulases and the bigger the diameter of halo, the higher the enzyme concentration for liquid culture have been reported by Liu et al., (2008), Theather and Wood (1982). The isolate was Gram positive, rod shaped, spore forming bacterium and aerobic. The $16 \mathrm{~S}$ rRNA gene sequence (accession no. KJ792668) of isolate CY-3 showed $99 \%$ similarity with Bacillus sonorensis and with the respect to this results of various morphological, biochemical molecular characteristic, it was classified as Bacillus species, belongs to phylum Fermicutes, class Bacilli, order Bacillales and family Bacillaceae (Fig. 8). The strain grew well between $30-60^{\circ} \mathrm{C}$ and at a wide $\mathrm{pH}$ range of 8.0 to 11.0 and the optimum enzyme synthesis occurred at $55^{\circ} \mathrm{C}$ and $\mathrm{pH} 9.0$ in the culture medium containing $0.6 \% \mathrm{CMC}$. The optimum incubation period for enzyme production was 48 hours. Alkaliphilles are defined as microbes growing optimally within $\mathrm{pH}$ 9.0-12.0, although the optimal $\mathrm{pH}$ varies depending on the growths conditions (Fujinama and Fujisawa, 2010; Arabaci et al., 2013). The bacterium is called typically alkaliphilic, as it grows optimally at $\mathrm{pH}$ values above 8.0 , but cannot grow or grows poorly at the near neutral $\mathrm{pH}$ value of 6.5 (Chang et al., 2012). Thermophilic bacteria are the organisms which can grow and produce such compounds optimally high temperature. Thermophiles are further subcategorized on the basis of their temperature tolerance: for instance, facultative thermophiles, can grow at temperatures between $50^{\circ} \mathrm{C}-65^{\circ} \mathrm{C}$, but also grow also at $37^{\circ} \mathrm{C}$; obligate thermophiles have maximum growth temperatures of $65^{\circ} \mathrm{C}-70^{\circ} \mathrm{C}$, and will not grow below $40^{\circ} \mathrm{C}$; extremely thermophiles can grow between $40^{\circ} \mathrm{C}-70^{\circ} \mathrm{C}$ with an optimal growth temperature of about $65^{\circ} \mathrm{C}$ and hyperthermophiles, mainly comprising of archae, can grow over $90^{\circ} \mathrm{C}$ with a range of optimal temperatures between $80^{\circ} \mathrm{C}-115^{\circ} \mathrm{C}$ (Horikoshi, 1999; Kikani et al., 2010). Specialized proteins called 'chaperonins' are produced by these organisms, which help, after their denaturation to returned the proteins to their native form and restore their functions and their cell membrane is made up of saturated fatty acids (Haki and Rakshit, 2003). According to these results the isolate Bacillus sp. CY-3 is called thermophilic and alkaliphilic bacterium.

Partial purified cellulase appeared as two different polypeptide band on SDS-PAGE and had the molecular masses of $80 \mathrm{kDa}$ and 72 $\mathrm{kDa}$, respectively (As shown in Figure 1). The similar result of this zymogram analyses was reported for the cellulases by Gelhaye et al (1993), Hoshino (2000), Coral et al (2002) and Odeniyi et al (2009). These results suggested that the enzyme have two subunits or dimeric structure (Arabaci et al., 2013).

On optimum $\mathrm{pH}$ analyses $\mathrm{CY}-3$ showed two peaks at $\mathrm{pH} 9.0$ and 11.0. But at $\mathrm{pH} 9.0$ was the activity value higher than $\mathrm{pH}$ 11.0. These results supported this zymogram analysis (Caf et al., 2012). And it was almost completely stable from $\mathrm{pH} 6.0$ to 12.0 for $60 \mathrm{~min}$ (about $\% 70$ residual activity, as shown in Fig.4.). The enzyme was extremely stable at 20 to $110^{\circ} \mathrm{C}$ after more than 60 min incubation with CMC substrate with more than 92\% macroactivity. These values are in accordance with these reports by Jang and Chen (2003), Wang et al., (2010) and Rostagi et al., (2010) for alkaline cellulase. This result are thought that the thermostable cellulase may provide spacious application in biopolishing process of cotton in the textile industry where requires cellulase stable at high temperature about $100^{\circ} \mathrm{C}$ and in the food and sugar industry, where high- temperature processes such as pasteurization are used (Haki and Rakshit, 
2003). In this study CMCase activity was stimulated by $\mathrm{Co}^{2+}$ to $121 \%$, while the presence $\mathrm{Mg}^{2+}$ reduced to $64 \%$. The results are quite similar to that reported for this enzyme from other source (Chang et al., 2011). $\mathrm{Co}^{2+}$ ions caused a significant increase (Mansfield et al., 1998; Christakopoulos et al., 1999; Chang et al., 2011) while $\mathrm{Mn}^{2+}$ caused a decrease in the activity of enzymes (Mawadza et al., 2000; Liu et al., 2008). In this study enzyme activitiy was stimulated by $\mathrm{Ca}^{2+}$ ions to $131 \%$. The activity was stimulated by $\mathrm{Ca}^{2+}$ ions rather than $\mathrm{Co}^{2+}$ ions. These results suggest that the enzymes required $\mathrm{Ca}^{2+}$ and $\mathrm{Co}^{2+}$ ions for thermal stability (Ito, 1997). $\mathrm{Ca}^{2+}$ ions had a considerable enhancement on the thermal stability. The stimulation by $\mathrm{Ca}^{2+}$ and $\mathrm{Co}^{2+}$ ions has been reported very unusual for alkaline endoglucanases (Christakopoulos et al., 1999; Liu et al., 2008; Lee et al., 2008). However, Mansfield et al (1998) reported that $\mathrm{Ca}^{2+}$ ions required by enzymes with the former increasing the substrate binding affinity of the enzyme, protecting them from conformational changes and stabilizing the conformation of the catalytic site. The $\mathrm{Ca}^{2+}$ binding sites determined for some bacterial enzymes contain a number of co-coordinating aspartic acid (Asp), glutamic acid (Glu) residues (Theather and Wood, 1982; Chang et al., 2012).

The inhibition by iodoacetamide (34\%) suggesting tryptophan and free thiol groups to be necessary for the enzyme activity. Tryptophan residues are not directly associated with active site but are essential for substrate binding in the cellulose binding domain of the cellulases (Bray et al., 2006; Lee et al., 2008). The non-ionic detergents Triton X-100, Tween 20, and Tween 80 and SDS showed slightly inhibitory effect, 31,29 , $30 \%$ respectively (Table 1). Similar findings have been made by other workers (Christakopoulos et al., 1999; Singh et al.,
2004; Chang et al., 2012). Cellulases for detergent use should maintain activity in their presence. These results showed that our enzyme is a good source for detergent additive (Arabaci et al., 2013).

In this study $\mathrm{Zn}^{2+}$ ions decreased activity of CMCase. The inhibition by $\mathrm{Zn}^{2+}(29 \%)$ can be a result of inhibitory effects of heavy metals on enzymes. This result suggested that these groups are present at the active site of the enzyme. Because of thiol groups are targets for the heavy metals. In another study was reported that the inhibition of enzymes by $\mathrm{Zn}$ is an indication of thermostability for an enzyme. In addition, the 1,10-phenantroline and EDTA decreased the activity of CMCase about 35\%. The massive inhibition observed against these inhibitors suggested that the partial purified cellulase is a metalloprotein (Theather and Wood, 1982; Chang et al., 2012). However, the CY-3 CMCase activity was slight inhibited $(13 \%)$ by PMSF $(3 \mathrm{mM})$. Thus, this result is thought that the enzyme do not possesses modification of a serine (ser) residue at the active site, because PMSF is known as serine protein inhibitors (Theather and Wood, 1982; Chang et al., 2012; Arabaci et al., 2013). On the other hand, it was found that the enzyme activity of CY-3 CMCase was not influenced by $\mathrm{H}_{2} \mathrm{O}_{2}$. Similar results have been reported by Joo and Chang (2005).

In conclusion the results of this study have shown that the enzyme CY-3 is a thermophilic, highly thermostable, alkaline, pH stable, highly resistant to $\mathrm{H}_{2} \mathrm{O}_{2}$ and other effectors (non-ionic detergents, SDS etc.) Cellulases for detergent use should maintain activity in their presence. These results showed that our enzyme is a good source for detergent additive. On the other hand, our enzyme showed optimum activity at $100^{\circ} \mathrm{C}$ with highly stability at $20-110^{\circ} \mathrm{C}$ for $60 \mathrm{~min}$ over than $92 \%$. This result are thought that the thermostable cellulase may provide spacious 
application in biopolishing process of cotton in the textile industry where requires cellulase stable at high temperature about $100^{\circ} \mathrm{C}$ (Haki and Rakshit, 2003) and in the food and sugar industry, where high- temperature processes such as pasteurization are used.

\section{Acknowledgement}

This research supported by the Cukurova University research found (FEF2011YL12).

\section{References}

Arabaci, N., Caf, Y., Maasoglu, Y., and Arikan,B. 2013. Partial Purification and Characterization of Thermostable, Alkaline and Chelator resistant Protease from a Newly Isolated Bacillus sp. CY7 and its potential applications in various industries. J. Appl. Biol. Sci., 7: 14-19.

Arikan, B., Unaldi, N., Coral, G., Colak, O., Aygan, A., and Gulnaz, O. 2003. Enzymatic properties of a novel thermostable, thermophilic, alkaline and chelator resistant amylase from an alkaliphilic Bacillus sp. isolate ANT-6. Proc. Biochem., 38: 1397-1403.

Balasubramanian, N., and Simoes, N. 2014. Bacillus pumilus S124A carboxymethyl cellulase; a thermo stable enzyme with a wide substrate spectrum utility. Int. J. Biol. Macromol., 67: 132-139.

Bray, M.R., Johnson, P.E., Gilkes, N.R., Mcintosh, L.P., Kilburn, D.G., and Waren, J.R.A. 2006. Probing the role of tryptophan residues in a cellulosebinding domain by chemical modification. Protein Sci., 5: 23112318.

Caf, Y., Valipour, E., and Arikan B. 2014. Study on cold-active and acidophilic cellulase (CMCase) from a novel psychrotrophic isolate Bacillus sp. K11. Int. J. Curr. Microbiol. App. Sci., 3(5): 16-25.
Caf, Y., Maasoglu, Y., Valipour, E., and Arikan, B. 2012. Production and characterization of novel cold-active, $\mathrm{pH}$ tolerant and detergent-stable: $\alpha$ amylase from a psychrotrophic bacterium from soil samples. New Biotechnol., 29: 23-26.

Cavaco-Paulo, A. 1998. Mechanism of cellulase action in textile processes. Carbohyd. Polym., 37: 273-277.

Chang, L., Ding, M., Bao, L., Chen, Y., Zhou, J., and Lu, H. 2011. Characterization of a bifunctional xylanase/endoglucanase from yak rumen microorganisms. Appl. Microbiol. Biotechnol., 90: 1933-1942.

Christakopoulos, P., Hatzinikolaou, D. G., Fountoukidis, G., Kekos, D., Claeyssens, M., and Macris, B.J. 1999. Purification and Mode of Action of an Alkali-Resistant Endo-1,4- $\beta$-glucanase from Bacillus pumilus. Arch. Biochem. Biophys., 364: 61-66.

Coral, G., Arikan, B., Ünaldı, M.N., and Güvenmez, H. 2002. Some Properties of Crude Carboxymethyl Cellulase of Aspergillus niger Z10 Wild-Type Strain. Turk. J. Biol., 26: 209-213.

Das A., Bhattacharya, S., and Murali, L. 2010. Production of cellulose from a thermophilic Bacillus sp. isolated from cow dung. American-Eurasian J. Agric. Environ. Sci., 8: 685-691.

Fujinama, S., and Fujisawa, M. 2010. Industrial applications of alkaliphiles and their enzymes- past, present and future. Environ. Technol., 31: 845-856.

Gelhaye, E., Gehin, A., Benoit, L., and Petitdemange, H. 1993. Effects of cellobiose on cellulose colonization by a mesophilic, cellulolytic Clostridium (strain C401). J. Gen. Microbiol., 139: 2819-2824.

Hafiz, A., 2005. Principles and reactions of protein extraction, purification, and characterization. pp 71-131. CRC Press, Boca Raton. 
Haki, G.D., and Rakshit, S.K. 2003. Developments in industrially important thermostable enzymes: a review. Biores. Technol., 89: 17-34.

Horikoshi, K., 1999. Alkaliphilles: Some applications of their products for biotechnology. Microbiol. Mol. Biol. Rev., 63(4): 735-750.

Hoshino, E., Chiwaki, M., Suzuki, A., and Murata, M. 2000. Improvement of Cotton Cloth Soil Removal by Inclusion of Alkaline Cellulase from Bacillus sp. KSM-635 in Detergents. J. Surfactants Deterg., 3: 317-326.

Ito, S. 1997. Alkaline cellulases from alkaliphilic Bacillus: Enzymatic properties, genetics, and application to detergents. Extremophiles, 1: 61-66.

Jang, D. H., and Chen, K. S. 2003. Production and characterization of thermostable cellulases from Streptomyces transformant T3-1. W. J. Microbiol Biotechnol., 19: 263-268.

Joo, H.S., and Chang, C.S. 2005. Production of protease from a new alkalophilic Bacillus sp. I-312 grown on soybean meal: optimization and some properties. Process Biochem., 40: 1263-1270.

Kikani, B.A., Shukla, R.J., and Singh, S.P. 2010. Biocatalytic potential of thermophilic bacteria and actinomycetes. pp. 1000-1007. In: Mendez-Vilas A. (ed). Technology and Education Topics in Applied Microbiology and Microbial Biotechnology. India.

Kim, J.Y., Hur, S.H., and Hong, J.H. 2005. Purification and characterization of an alkaline cellulase from a newly isolated alkalophilic Bacillus sp. HSH-810. Biotechnol. Lett., 27: 313-316.

Lee, Y. J., Kim, B. K., Lee, B. H., Jo, K. I., Lee, N. K., Hung, C. H., Lee, Y. C., and Lee, J. W.2008. Purification and characterization of cellulase produced by Bacillus amyoliquefaciens DL-3 utilizing rice hull. Biores. Technol., 99: 378-386.

Liu S. L., Chen, W. Z., Wang, Y., Liu, G., Yu, S. W., and Xing M. 2008. Purification and Characterization of a novel neutral $\beta$-glucanase and an alkaline $\beta$-glucanase from an alkaliphilic Bacillus isolate. World J. Microbiol. Biotechnol., 24:149-155.

Lowry, O.H., Rosebrough, N.J., Farr, A.L., and Randall, R.J. 1951. Protein measurement with the Folin phenol reagent. J. Biol. Chem., 193: 265-275.

Mansfield, S.D., Saddler, J.N., and Gübitz, G.M. 1998. Characterization of endoglucanases from the Brown rot fungi Gloeophyylum sepiarium and Gloephyylum traberum. Enzyme Microb. Biotechnol., 23: 133-140.

Mawadza, C., Hatti-Kaul, R., Zvauya, R., and Mattiasson, B. 2000. Purification and characterization of cellulases produced by two Bacillus strains. J. Biotechnol., 83: $177-187$.

Nielsen, P. H., Oxenboll, K. M., and Wenzel, H. 2007. Cradle-to-Gate environmental assessment of enzyme products produced industrially in Denmark by Novozymes A/S. Int. J. Life Cycle Assess., 12: 432-438.

Odeniyi, O. A., Onilude, A. A., and Ayodele, M. A. 2009. Production characteristics and properties of cellulase/polygalacturonase by a Bacillus coagulans strain from a fermenting palm-fruit industrial residue. Afr. J. Microbiol. Res., 3: 407-417.

Rastogi, G., Bhalla, A., Adhikari, A., Bischoff, K. M., Hughes, S. R., Christopher, L. P., and Sani R.K. 2010. Characterization of thermostable cellulases produced by Bacillus and Geobacillus strains. Biores. Technol., 101: 8798-8806.

Shanmughapriya, S., Seghal, G., Selvin, J., Thomas, T.A., Rani, C. 2010. 
Optimization, Purification, and Characterization of Extracellular Mesophilic Alkaline Cellulase from Sponge-Associated Marinobacter sp. MSI032. Appl. Biochem. Biotechnol., 162: 625-640.

Singh, J., Batra, N., and Sobti, R. C. 2001. A highly thermpstable, alkaline CMCase produced by a newly isolated Bacillus sp. VG1. World J. Microbiol. Biotechnol., 17: 761-765.

Singh, J., Batra, N., and Sobti, R. C. 2004. Purification and characterisation of alkaline cellulase produced by a novel isolate, Bacillus spaericus JS1. J. Ind. Microbiol. Biotechnol., 31: 51-56.

Sousa, F., Jus, S., Erbel, A., Kokol, V., Cavaco-Paulo, A., and Gubitz, G. M. 2007. A novel metalloprotease from Bacillus cereus for protein fibre processing. Enzyme Microb. Tech., 40: 1772-1781.

Theather, R. M., and Wood, P. J. 1982. Use of congo red-polysaccharide interaction in enumeration and characterization of cellulilytic bacteria from the bovine rumen. Appl. Environ. Microbiol., 43: 777-780.

Tormo, J., Lamed, R., Chirino, A. J., Morag, E., Bayer, E. A., Shoham, Y., and Steitz, T. A. 1996. Crystal structure of a bacterial family-III cellulose-binding domain: a general mechanism for attachment to cellulose. Embo J., 15: 5739-51.

Trivedi, N., Gupta, V., Kumar, M., Kumari, P., Reddy, C. R. K., and Jha, B.2011. An alkali-halotolerant cellulase from Bacillus flexus Isolated from green seaweed Ulva lactuca. Carbohyd. Polym., 83: 891-897.

Voget, S., Steele, H.L., and Streit, W.R. 2006. Characterization of a metagenomederived halotolerant cellulase. $J$. Biotechnol., 126: 26-36.

Vos, P., Garrity, G., Jones, D., Krieg, N. R., Ludwig, W., Rainey, F. A., Schleifer, K. H., and Whitman, W.2009. Bergey's Manual of Systematic Bacteriology Volume 3: The Firmicutes. Springer, New York.

Wang, Y., Wang, X., Tang, R., Yu, S., Zheng, B., and Feng, Y.2010. A novel thermostable cellulase from Fervidobacterium nodosum. J. Mol. Catalysis B. Enzymatic, 66: 294-301.

$\mathrm{Xu}$, Q., Adney, W.S., Ding, S.Y., and Himmel, M.E. 2007. Cellulases for Biomass Conversion. pp. 35-50. In: Polaina J., and Maccabe P. (eds.). Industrial Enzymes Structure, Function and Applications. USA.

\section{How to cite this article:}

Yasemin Caf and Burhan Arikan. 2017. A Novel Alkaline, Highly Thermostable and Oxidant Resistant Carboxymethyl Cellulase (Cmcase) Produced by Thermophilic Bacillus sonorensis CY-3. Int.J.Curr.Microbiol.App.Sci. 6(3): 2349-2362. doi: http://doi.org/10.20546/ijcmas.2017.603.269 